\section{Behaviour of Listeria monocy- togenes and Escherichia coli 0157:H7 during the cheese making of traditional raw-milk cheeses from Italian Alps}

\author{
Elena Cosciani-Cunico,' Elena Dalzini,' \\ Stefania Ducoli, ${ }^{1}$ Chiara Sfameni,' \\ Barbara Bertasi," Marina-Nadia Losio,2 \\ Paolo Daminelli, ${ }^{1}$ Giorgio Varisco' \\ 'Department of Food Microbiology, \\ Veterinary Public Health Institute of \\ Lombardy and Emilia Romagna Brescia; \\ ${ }^{2}$ Veterinary Public Health Institute of \\ Lombardy and Emilia Romagna, Brescia, \\ Italy
}

\section{Abstract}

The behaviour of Listeria monocytogenes and Escherichia coli 0157:H7 was studied during the manufacture and ripening of two traditional Italian Alps cheeses. Each cheese type was manufactured in a pilot plan from raw cow milk (without the addition of starter cultures) artificially inoculated with $L$. monocytogenes and $E$. coli $0157: \mathrm{H} 7$ to a final concentration of about $4 \log \mathrm{CFU} / \mathrm{mL}$. The pathogens were enumerated throughout the cheese making and ripening processes to study their behaviour. When the milk was inoculated with 4 Log $\mathrm{CFU} / \mathrm{mL}$, the pathogens counts increased in the first time during the manufacturing process and then remained constant, until the end of ripening, or decreased significantly. Results indicate that the environment and nature of food borne pathogens affected the concentration of the bacteria during the manufacturing and ripening process. Thus, the presence of low cells numbers of $L$. monocytogenes and $E$. coli $0157: \mathrm{H} 7$ in milk destined for the production of raw milk cheeses characterized by a cooking of the curd less than $48^{\circ} \mathrm{C}$ can constitute a hazard for the consumer.

\section{Introduction}

The food business operators (FBOs) have to check the hygiene of their production following the European Commission (EC) Regulation No. 2073/2005 (European Commission, 2005). In the online database, Rapid Alert System for Food and Feed (RASFF), created by the EC, it is published that, in the last ten years, 55 alerts were regarding the presence of Listeria monocytogenes and verocytotoxin Escherichia coli (VTEC) in raw milk cheeses, mainly produced in France (RASFF, 2007). In fact, among dairy products, the raw milk cheese, characterized by the cooking of the curd at temperature less than $48^{\circ} \mathrm{C}$, are known to be the most frequently contaminated (CDSC, 2000; Conedera et al., 2004; Bielaszewska et al., 1997; EFSA, 2013; Farrokh et al., 2013) and it is documented that contaminated raw milk cheeses, with short ripening time (less than 60 days) could generate severe outbreak (Health Canada, 2013).

Many regional cheeses throughout Europe are manufactured from unpasteurized milk, and there is growing concern that fresh cheeses, made by raw milk, could be contaminated by food pathogens (Vernozy-Rozand $e t$ al., 2005). Traditional, raw milk cheeses, obtained by the cooking of the curd at temperature less than $48^{\circ} \mathrm{C}$, are produced in Alps area, and while more data are available for the French cheeses (Miszczycha et al., 2013) few is known about the behaviour of food pathogens during the cheese making of Italian raw milk cheeses produced in Alps area.

The cheese manufacturing process affects strongly the eco-system in which the food pathogen could be present. The cheese making temperature, the $\mathrm{pH}$ and $\mathrm{a}_{\mathrm{w}}$ reduction, the presence of indigenous bacterial population, are all variables that can modify the behaviour of undesirable bacteria (Buchanan et al., 1993). For this reason, many cheese making processes are registered in the Minister of Health web site on quality and safety of Italian food product (www.ars-alimentaria.it).

The purpose of this work was to study the behaviour of $L$. monocytogenes and $E$. coli 0157:H7 in two cheeses produced in Alps area, by challenge test performed in a pilot plan at the Veterinary Public Health Institute of Lombardy and Emilia Romagna, Brescia, Italy.

\section{Materials and Methods}

\section{Raw milk}

A total of $700 \mathrm{~L}$ of raw cow milk were collected at different time during the summer season in the Alps in Northern Italy. Milk was collected from the bulk ripening tank and maintained refrigerated at $4 \pm 0.5^{\circ} \mathrm{C}$ for transportation to the pilot plan and processed immediately.

\section{Bacterial cultures}

Two multi-strain cocktails of $L$. monocytogenes and $E$. coli $0157: \mathrm{H} 7$ were used in this experiment. L. monocytogenes ATCC ${ }^{\circledR} 19115$ and two wild strains (isolated from cheeses; BVR; www.ibvr.org) and E. coli 0157:H7 ATCC ${ }^{\circledR} 35150$ and two wild strains (isolated from milk; BVR; www.ibvr.org) were used in the challenge test. The bacterial cultures were prepared in agreement with Dalzini et al.
Correspondence: Elena Cosciani-Cunico, Department of Food Microbiology, Veterinary Public Health Institute of Lombardy and Emilia Romagna, via A. Bianchi 9, 25124 Brescia, Italy. Tel. +39.030 .2290543 - Fax: +39.030 .2290542 .

E-mail: elena.coscianicunico@izsler.it

Acknowledgements: the authors are grateful to Dr. Paola Monastero and Alessandro Norton (Food microbiology laboratory, Veterinary Public Health Institute of Lombardy and Emilia Romagna) for scientific support and technical assistance.

Conflict of interest: the authors declare no potential conflict of interest.

Received for publication: 17 July 2014.

Revision received: 21 January 2015.

Accepted for publication: 21 January 2015.

This work is licensed under a Creative Commons Attribution 3.0 License (by-nc 3.0).

(C) Copyright E. Cosciani-Cunico et al., 2015 Licensee PAGEPress, Italy

Italian Journal of Food Safety 2015; 4:4585

doi:10.4081/ijfs.2015.4585

(2015). Raw milk was separately inoculated with two multi-strain cocktails, with the ratio of $1: 100 \mathrm{v} / \mathrm{v}$, in order to obtain an initial milk contamination of about $4 \mathrm{Log} \mathrm{CFU} / \mathrm{g}$ (contaminated cheese). For the production of not contaminated cheeses the milk was inoculated with sterile peptone water (PW) (CONDA, Madrid, Spain) at the same ratio.

\section{Cheese preparation}

Two different cheeses were manufactured in pilot plan. Both types of cheeses were done following specifications of producers (www.ars-alimentaria.it). The manufacturing process were summarized in Table 1 (for cheese A) and in Table 2 (for cheese B). In order to produce cheese A (short ripened cheese), a total of $150 \mathrm{~L}$ of raw cow milk was used. During the process, no heat treatment was applied to the curd. Cheeses were ripened on wooden boards at $4-5^{\circ} \mathrm{C}$ for 60 days with turning over every 1-3 days. A total of 30 cheeses ( $1 \mathrm{~kg}$ each) were obtained: 10 cheeses contaminated with $L$. monocytogenes, 10 cheeses contaminated with $E$. coli and 10 non contaminated cheeses. In order to produce cheese B (long ripening cheese), a total of 150 $\mathrm{L}$ were used. The curd was cooked at $45^{\circ} \mathrm{C}$ for $15 \mathrm{~min}$ and then moulded into 80 by $300 \mathrm{~mm}$ cylindrical wooden moulds. Cheeses were ripened at $12^{\circ} \mathrm{C}$ for 4 months. Five cheeses, 8 $\mathrm{kg}$ each, were obtained.

\section{Bacterial and physico-chemical analysis}

While the milk was not diluted, the solid 
samples were transferred in a sample bags (NEOMED, Milan, Italy) and homogenized 1:3 w/v in sterile PW for 3 min in a Stomacher 400 blender (Seward Medical, London, UK). Serial 10 fold dilutions of control samples test material were prepared in sterile PW. In contaminated samples, the enumeration of $E$. coli 0157:H7 was performed in agreement with Vernozy-Rozand et al. (2005) and CoscianiCunico et al. (2014), while the L. monocytogenes enumeration was carried out according to the standard method ISO 11290-2 (ISO, 1998a). To verify the natural contamination of raw milk, at time zero, the enumeration of pathogens was also investigated in not contaminated samples.

In not contaminated samples, the enumeration of lactic acid bacteria (LAB) was performed according to the standard methods ISO 15214 (ISO, 1998b). All analyses were carried out in milk, curd after the extraction, and in cheese at different sampling times during the ripening step.

The physical-chemical analyses were carried out in not contaminated sample. The $\mathrm{pH}$ values (Hanna Instrument, Woonsocket, RI, USA), and the water activity $\left(\mathrm{a}_{\mathrm{w}}\right)$ (Decagon Devices, Inc., Pullman, WA, USA) were measured.

\section{Statistical analysis}

For the short ripened cheese, the average and standard deviations of $L$. monocytogenes and $E$. coli $0157: \mathrm{H} 7$ microbial counts were determined from the average of three samples at each sampling time, while the average and standard deviations of LAB microbial counts, as well for the physical-chemical values, were determined from the average of two samples at each sampling time.

For the long ripened cheese, the average and standard deviations of $L$. monocytogenes and $E$. coli $0157: \mathrm{H} 7$ microbial counts were determined from the average of two samples at each sampling time, while LAB microbial counts, as well for the physical-chemical values, were determined from a single sample at each sampling time.
Analysis of variance (ANOVA) was carried out. The significance was statistically analysed by Student $t$-test at a $95 \%$ confidence interval $(\mathrm{P}<0.05)$ using $\mathrm{R}$ statistical software version 2.7.0 (R Development Core Team, 2008).

Table 1. Conditions of manufacturing process of short ripened cheese (cheese A), made from raw milk, from the cheese making to the end of ripening time.

\begin{tabular}{lcc}
\hline Manufacturing step & Duration (hours) & Temperature $\left({ }^{\circ} \mathrm{C}\right)$ \\
Addition of cheese rennet* & $0.5(0.02)$ & 32 \\
Acidification and coagulation & $0.75(0.03)$ & $22-18$ \\
\hline Cutting coagulum into $0.5 \mathrm{~cm}$ cubes and sineresis & $1(0.04)$ & $22-18$ \\
Moulding $^{\circ}$ & $0.5(0.02)$ & $22-18$ \\
\hline Draining and overturning & $24(1)$ & $22-18$ \\
Manual salting & $0.5(0.02)$ & $22-18$ \\
\hline Draining and inversion & $48(2)$ & $22-18$ \\
Ripening & $1368-1440(57-60)$ & $5-6$ \\
\hline
\end{tabular}

*1:10000 mL/mL; ${ }^{\circ} 40$ by $200 \mathrm{~mm}$ quadratic wooden moulds. Values in parenthesis represent days.

Table 2. Conditions of manufacturing process of long ripened cheese (cheese B) made from raw milk, from the cheese making to the end of shelf life.

\begin{tabular}{lcc} 
Manufacturing step & Duration (hours) & Temperature $\left({ }^{\circ} \mathrm{C}\right)$ \\
Addition of cheese rennet* & $0.5(0.02)$ & 36 \\
Acidification and coagulation & $0.5(0.02)$ & 21 \\
\hline Cutting of the coagulum in 4 cm cubes & $1(0.04)$ & 21 \\
and then in grains of rice & & $45-48$ \\
Cooking of the curd, sineresis & $0.25(0.01)$ & 38 \\
\hline Moulding $^{\circ}$ & $0.5(0.02)$ & 21 \\
Pressing of the curd & $3(0.125)$ & $20-18$ \\
\hline Draining and overturning & $36(1.5)$ & 12 \\
Manual salting & $192(8)$ & 12 \\
\hline Ripening & $1488(120)$ &
\end{tabular}

${ }^{*} 1: 10000 \mathrm{~mL} / \mathrm{mL} ;{ }^{\circ} 80$ by $300 \mathrm{~mm}$ cylindrical wooden moulds. Values in parenthesis represent days.

Table 3. $\mathrm{p}_{\mathrm{H}}$, aw values and lactic acid bacteria concentration in milk, curd and cheeses during manufacturing and ripening.

\begin{tabular}{|c|c|c|c|c|}
\hline Cheese type & Test material & $\mathrm{pH}$ & $a_{w}$ & LAB (Log CFU/mL, CFU/g) \\
\hline Cheese A & $\begin{array}{c}\text { Milk } \\
\text { Curd } \\
\text { Cheese }(1)^{\circ} \\
\text { Cheese }(15)^{\circ} \\
\text { Cheese }(30)^{\circ} \\
\text { Cheese }(60)^{\circ}\end{array}$ & $\begin{array}{c}6.75 \pm 0.03 \\
6.5 \pm 0.08 \\
5.56 \pm 0.3 \\
5.24 \pm 0.09 \\
5.39 \pm 0.06 \\
5.4 \pm 0.15\end{array}$ & $\begin{array}{c}\text { ND } \\
0.967 \pm 0 \\
0.981 \pm 0.002 \\
0.983 \pm 0.01 \\
0.971 \pm 0.006 \\
0.947 \pm 0.007\end{array}$ & $\begin{array}{c}4.66 \pm 0.01 \\
8.38 \pm 0.05 \\
9.22 \pm 0.11 \\
9.42 \pm 0.08 \\
9.2 \pm 0.08 \\
8.93 \pm 0.25\end{array}$ \\
\hline Cheese B & $\begin{array}{c}\text { Milk } \\
\text { Curd } \\
\text { Cheese }(1)^{\circ} \\
\text { Cheese }(3)^{\circ} \\
\text { Cheese }(7)^{\circ} \\
\text { Cheese }(10)^{\circ} \\
\text { Cheese }(20)^{\circ} \\
\text { Cheese }(30)^{\circ} \\
\text { Cheese }(60)^{\circ} \\
\text { Cheese }(90)^{\circ} \\
\text { Cheese }(120)^{\circ}\end{array}$ & $\begin{array}{l}6.73 \\
6.68 \\
6.03 \\
5.12 \\
5.24 \\
5.22 \\
5.11 \\
5.11 \\
5.02 \\
5.04 \\
5.12\end{array}$ & $\begin{array}{c}\text { ND } \\
0.991 \\
0.994 \\
0.993 \\
0.989 \\
0.997 \\
0.968 \\
0.96 \\
0.95 \\
0.956 \\
0.951\end{array}$ & $\begin{array}{l}4.07 \\
6.81 \\
8.57 \\
8.77 \\
8.99 \\
9.07 \\
8.96 \\
8.83 \\
8.77 \\
8.65 \\
8.67\end{array}$ \\
\hline
\end{tabular}

$\mathrm{LAB}$, lactic acid bacteria; ND, not determined; CFU, colony forming unit. ${ }^{\circ}$ Day of ripening. Values are represented as mean \pm standard deviation of two replicates samples for the short ripened cheese (A); while as a single value for long ripened cheese (B). Values in parenthesis represent days. 


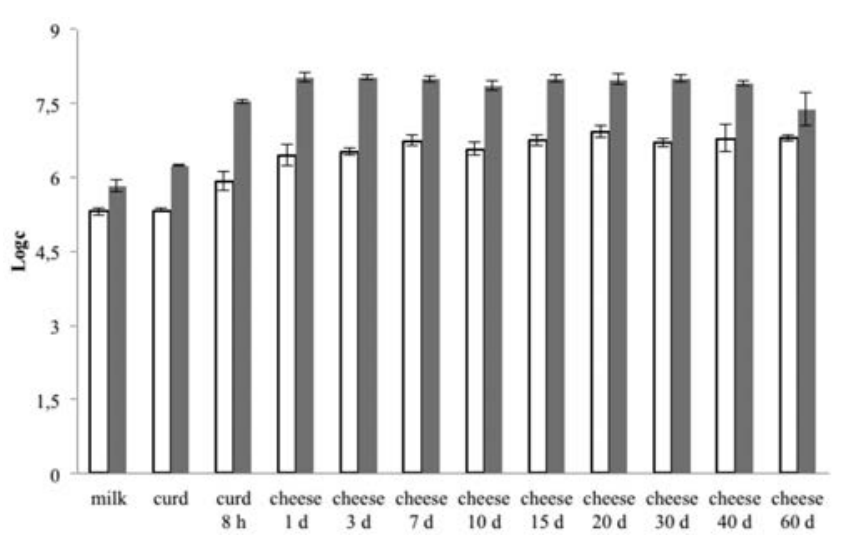

Figure 1. Logc concentration of Listeria monocytogenes (white bars) and Escherichia coli $0157: \mathrm{H} 7$ (grey bars), throughout the cheese making and ripening of short ripened cheese. Values are obtained from the average and standard deviations of three samples at each sampling time.

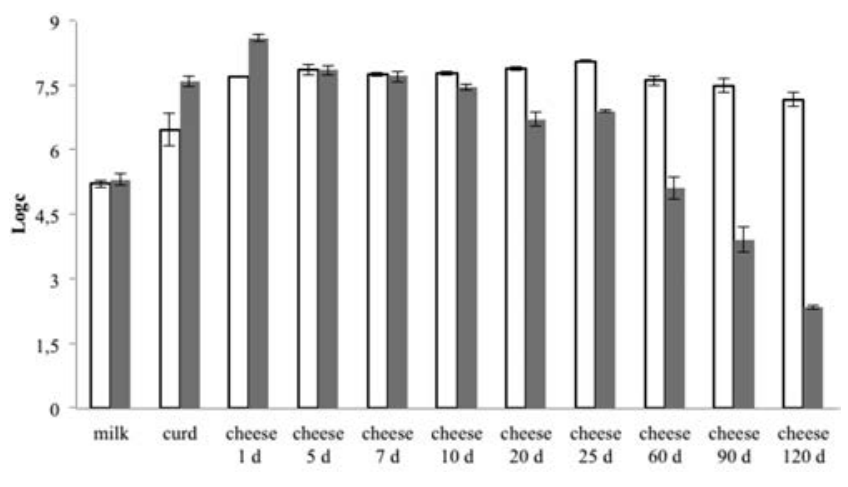

Figure 2. Logc concentration of Listeria monocytogenes (white bars) and Escherichia coli O157:H7 (grey bars), throughout the cheese making and ripening of long ripened cheese. Values are obtained from the average and standard deviations of two samples at each sampling time.

\section{Results}

Microbiological analysis in not contaminated milk revealed the absence $(<0.47 \mathrm{log}$ $\mathrm{CFU} / \mathrm{mL}$ ) of $E$. coli 0157 and $L$. monocytogenes (data not shown). The LAB concentration and the physical-chemical properties of milk, curds and cheeses measured on not contaminated cheeses, were shown in Table 3 . In the cheese with a short ripening time (cheese $\mathrm{A}$ ) the $\mathrm{pH}$ decreased during the coagulation step, reaching $\mathrm{pH} 5.56 \pm 0.3$ at the end of the draining, and remained almost stable until the end of ripening ( $\mathrm{pH} 5.4 \pm 0.15)$. In the cheese with a long ripening time (cheese $\mathrm{B}$ ) the $\mathrm{pH}$ reached, after 3 days, the $\mathrm{pH} 5.12$ and remained constantly low until the end of the ripening. The $a_{w}$ decreased gradually during the ripening until it reached almost 0.95 in both cheeses. Analyses of raw milk indicated that, before the cheese making, the $\mathrm{LAB}$ concentration was 4.66 and $4.07 \mathrm{Log}$ CFU/mL respectively in cheese A and B. During the process, LAB concentration increased up to 9.22 and $8.57 \mathrm{Log}$ $\mathrm{CFU} / \mathrm{g}$ in both cheeses and remained relatively stable during the ripening step. Different $E$. coli $0157: \mathrm{H} 7$ and $L$. monocytogenes behaviour were observed during both manufacturing processes. In both contaminated cheese types, the pathogen concentrations increased significantly during the first hours of the manufacturing process (Figures 1 and 2). This can be due to the concentration of milk proteins in the curd (Miszczycha et al., 2013). While $L$. monocytogenes concentration remained stable during the ripening time in both cheeses, the concentration of $E$. coli $0157: \mathrm{H} 7$ remained stable during the ripening time of short ripening cheese, but decreased significantly $(\mathrm{P}>0.05$, more than $6 \mathrm{Log} \mathrm{CFU} / \mathrm{g}$ ) in long ripening cheese (Figures 1 and 2).

\section{Discussion}

In the present study we observed as the manufacturing process of raw milk cheese can affect the behaviour of two important food pathogens such as $L$. monocytogenes and $E$. coli 0157:H7 in different ways. In fact, the cheese-making process and the physical chemical variables of the two cheeses are different and this seems to affect more the behaviour of the Gram negative $E$. coli than the Gram positive $L$. monocytogenes (El-Ziney et al., 1998). In particular, the L. monocytogenes concentration remained stable during the type manufacturing process of both cheeses and showed a low variability during the ripening step. The pathogen reached the apparent stationary phase at the beginning of ripening time and remained constant. This can be explained considering that the amount of organic acid, produced by the lactic acid bacteria, inhibited the growth of $L$. monocytogenes (Le Marc et al., 2002; Mellefont et al., 2008; Cornu et al., 2011). During the short ripened cheese type process, even the $E$. coli $0157:$ H7 concentration did not change, as previously reported in a Formaggella produced in the northwest area of Lombardy region (Cosciani-Cunico et al., 2014). Conversely, in the long ripened cheese, the pathogen concentration decreased significantly, which can be due to the lower $\mathrm{pH}$ of cheese during the ripening step (under 5.3 value) in agreement with Buchanan (1993). The same result was previously observed in a French goat cheese made with raw milk in which E. coli 0157:H7 concentration decreased gradually during the ripening phase (Vernozy-Rozand et al., 2005).

\section{Conclusions}

The present study confirms the influence of the cheese-manufacturing environment on the L. monocytogenes and E. coli 0157:H7 growths, in particular during the first days of the process as reported by others authors in different cheese types (Ryser and Marth, 1987; Ramsaran et al., 1998; www.combase.cc). Results indicate that $L$. monocytogenes and $E$. coli $0157: \mathrm{H} 7$ can survive the manufacturing process. Thus, the presence of low numbers of these pathogens in milk, destined for the production of raw milk cheeses characterized by a short ripening time, can constitute a threat to the consumer. Even $L$. monocytogens did not decrease during the ripening of the long ripening time cheese, considered in this study, while $E$. coli $0157: \mathrm{H} 7$ decreased significantly. Knowing the intrinsic end extrinsic variables of these two traditional Italian Alps cheeses, observed data reported in this study could be used to validate dynamic predictive mathematical model published in the literature (Baranyi and Roberts, 1995).

\section{References}

Baranyi J, Roberts TA, 1995. Mathematics of predictive food microbiology. Int J Food Microbiol 26:199-218.

Bielaszewska M, Janda J, Blahova K, Minarikova H, 1997. Human Escherichia coli 0157:H7 infection associated with the consumption of unpasteurized goat's milk. Epidemiol Infect 119:299-305.

Buchanan RL, 1993. Developing and distributing user-friendly application software. J 
Ind Microbiol 12:251-5.

Buchanan RL, Golden MH, Whiting RC, 1993. Differentiation of the effects of $\mathrm{pH}$ and lactic or acetic concentration on the kinetics of Listeria monocytogenes inactivation. $\mathrm{J}$ Food Protect 56:474-8.

CDSC, 2000. Communicable disease report. CDR Weekly 10:171.

Conedera G, Dalvit P, Martini M, Galiero G, Gramaglia M, Goffredo E, Loffredo G, Morabito S, Ottaviani D, Paterlini F, Pezzotti G, Pisanu M, Semprini P, Caprioli A, 2004. Verocytotoxin-producing Escherichia coli 0157 in minced beef and dairy products in Italy. Int J Food Microbiol 96:67-73.

Cornu M, Billoir E, Bergis H, Beaufort A, Zuliani V, 2011. Modeling microbial competition in food: application to the behavior of Listeria monocytogenes and lactic acid flora in pork meat products. Food Microbiol 28:639-47.

Cosciani-Cunico E, Dalzini E, D’Amico S, Sfameni C, Bertasi B, Losio MN, Giacometti F, Daminelli P, 2014. Behaviour of Escherichia coli 0157: H7 during the manufacture and ripening of an Italian traditional raw goat milk cheese. Ital J Food Safety 3:2243.

Dalzini E, Cosciani-Cunico E, Bernini V, Bertasi B, Losio MN, Daminelli P, Varisco G, 2015. Behaviour of Escherichia coli 0157 (VTEC), Salmonella Typhimurium and Listeria monocytogenes during the manufacture, ripening and shelf life of low fat salami. Food Control 47:306-11.

EFSA, 2013. The European Union summary report on trends and sources of zoonoses, zoonotic agents and food-borne outbreaks in 2011. EFSA J 2013;11:3129-250.

El-Ziney MG, Debevere JM, 1998. The effect of reuterin on Listeria monocytogenes and Escherichia coli 0157: H7 in milk and cottage cheese. J Food Protect 61:1275-80.

European Commission, 2005. Regulation of the European Parliament and of the Council of 15 November 2005 on microbiological criteria for foodstuffs, 2073/2005/CE. In: Official Journal, L 338/1, $22 / 12 / 2005$.

Farrokh C, Jordan K, Auvray F, Glass K, Oppegaard H, Raynaud S, Cerf 0, 2013. Review of Shiga-toxin-producing Escherichia coli (STEC) and their significance in dairy production. Int $\mathrm{J}$ Food Microbiol 162:190-2.

Health Canada, 2013. Epidemiological information: E. coli 0157:H7 illness related to cheese produced by Gort's Gouda cheese farm. Available from: http://www.phacaspc.gc.ca/fs-sa/phn-asp/2013/ecoli-epiinfo-0913-eng.php

ISO, 1998a. Microbiology of food and animal feeding stuffs. Horizontal method for the detection and enumeration of Listeria monocytogenes. Part 2: Enumeration Method. ISO Norm 11290-2:1998/Amd. 1:2004. International Organization for Standardization, Geneva, Switzerland.

ISO,1998b. Microbiology of food and animal feeding stuffs. Horizontal method for the enumeration of mesophilic lactic acid bacteria. Colony count technique at $30^{\circ} \mathrm{C}$. ISO Norm 15214:1998. International Organization for Standardization, Geneva, Switzerland.

Le Marc Y, Huchet V, Bourgeois CM, Guyonnet JP, Mafart P, Thuault D, 2002. Modelling the growth kinetics of Listeria as a function of temperature, $\mathrm{pH}$ and organic acid concentration. Int J Food Microbiol 73:21937.

Mellefont LA, McMeekin TA, Ross T, 2008. Effect of relative inoculum concentration on Listeria monocytogenes growth in coculture. J Food Microbiol 112:157-68.

Miszczycha SD, Perrin F, Ganet S, Jamet E, Tenenhaus-Aziza F, Montel MC, ThevenotSergentet D, 2013. Behavior of different shiga toxin-producing Escherichia coli serotypes in various experimentally contaminated raw-milk cheeses. Appl Environ Microb 79:150-8.

R Development Core Team, 2008. R: a language and environment for statistical computing. R Foundation for Statistical Computing, Vienna, Austria.

Ramsaran H, Chen J, Brunke B, Hill A, Griffiths MV, 1998. Survival of bioluminescent Listeria monocytogenes and E. coli 0157:H7 in soft cheese. J Dairy Sci 81:1810-7.

RASFF, 2007. Directorate general for health and consumer protection. European Commission, Brussels, Belgium.

Ryser T, Marth EH, 1987. Fate of Listeria monocytogenes during the manufacture and ripening of camembert cheese, J Food Protect 50:372-8.

Vernozy-Rozand C, Mazuy-Cruchaudet C, Bavai C, Montet MP, Bonin V, Dernburg A, Richard Y, 2005. Growth and survival of Escherichia coli 0157:H7 during the manufacture and ripening of raw goat milk lactic cheeses. Int J Food Microbiol 105:83-8. 